\title{
HILGARDIA
}

A Journal of Agricultural Science Published by the California Agricultural Experiment Station

CONTENTS

THE EFFECT OF CERTAIN ADDED MATERIALS ON BORDEAUX MIXTURE INTHE CONTROL OF PEACH BLIGHT AND LEAF CURL EDWARD E. WIISON

PHYTOPHTHORA CINNAMOMI AND WET SOIL IN RELATION TO THE DYING-BACK OF AVOCADO TREES

VINCENT A. WAGER

PYTHIACEOUS FUNGI ON CITRUS VINCENT A. WAGER

UNIVERSITY OF CALIFORNIA - BERKELEY, CALIFORNIA 


\section{PYTHIACEOUS FUNGI ON CITRUS}

VINCENT A. WAGER 



\title{
PYTHIACEOUS FUNGI ON CITRUS ${ }^{1,2}$
}

\author{
VINCENT A. WAGER ${ }^{3}$
}

Pythiaceous fungi on citrus in California were investigated during the season 1939-40. In the course of this investigation, citrus roots were examined for the presence of fungi, inoculation experiments were performed on citrus fruits with pythiaceous fungi from citrus in general, and growth-temperature relations of Phytophthora species found on citrus were studied. This paper reports the results of this work, and includes a compilation of records on the geographic distribution of Phytophthora on citrus and a description of all Phytophthora and Pythium species recorded on citrus.

\section{PYTHIACEOUS FUNGI ON ROOTS OF CITRUS}

In previously reported work on the isolation of fungi from roots of citrus, Fawcett (3) ${ }^{4}$ states that species of Pythium and Phytophthora have been found to be associated with the damping-off and death of young citrus trees. Weindling (11) isolated Phytophthora parasitica Dastur and Pythium spp. from citrus seedlings affected with this disease in California, and Perlberger (5) found Phytophthora citrophthora (Sm. and Sm.) Leonian and Phytophthora parasitica in the same connection in Palestine. Fawcett (1) recorded the finding of Phytophthora citrophthora and Phytophthora parasitica in 1923 on large citrus roots and showed that the former would attack small roots of lemon trees. He $(2,3)$ also found Phytophthora megasperma Drechsl. on the fibrous roots of orange trees dying back in heavy clay soil in Tulare County, California. In 1935, Petri (6) found Pythium megalacanthum de Bary and Pythium de Baryanum Hesse associated with root rot of oranges in Catania, Italy.

In order to explore the possibility that species of Phytophthora or some other fungi might be playing a more active part in producing disease in citrus trees in California than had hitherto been suspected, large numbers of roots were examined from citrus trees that showed a

\footnotetext{
${ }^{1}$ Received for publication May 19, 1941.

2 Paper No. 456, University of California Citrus Experiment Station, Riverside, California.

${ }^{3}$ Plant Pathologist, Union of South Africa Department of Agriculture. On Commonwealth Fellowship in collaboration with the Division of Plant Pathology, University of California Citrus Experiment Station, Riverside, California, September, 1939, to June, 1940.

"Italic numbers in parentheses refer to "Literature Cited" at the end of this paper.
} 
dying-back, or decline. Orange and lemon trees growing in various localities in southern California were inspected.

Roots from the diseased trees were carefully washed in water ; portions of the dead fibrous roots, about $1 \mathrm{~cm}$ long, were then surface-sterilized and placed on petri dishes poured with oatmeal agar. Culture tests were made from 320 fibrous roots of orange and 152 fibrous roots of lemon. The nonpythiaceous fungus Fusarium Solani (Mart.) App. and Wr. was found on most of the roots from all localities. ${ }^{6}$ Table 1 shows the pythiaceous fungi found and the frequency of their occurrence.

TABLE 1

Pythiaceous Fungi Isolated from Fibrous Roots of Citrus Trees VARIOUSLY LOCATED*

\begin{tabular}{|c|c|c|c|c|}
\hline \multirow[b]{2}{*}{ Fungus } & \multicolumn{2}{|c|}{ Orange roots } & \multicolumn{2}{|c|}{ Lemon roots } \\
\hline & $\begin{array}{c}\text { Number } \\
\text { of } \\
\text { localities } \\
\text { where } \\
\text { found }\end{array}$ & $\begin{array}{c}\text { Number } \\
\text { of roots } \\
\text { infected, } \\
\text { of } 320 \\
\text { tested }\end{array}$ & $\begin{array}{c}\text { Number } \\
\text { of } \\
\text { localities } \\
\text { where } \\
\text { found }\end{array}$ & $\begin{array}{c}\text { Number } \\
\text { of roots } \\
\text { infected, } \\
\text { of } 152 \\
\text { tested }\end{array}$ \\
\hline Phytophthora citrophthora... & 4 & 6 & 1 & 3 \\
\hline Phytophthora parasitica..... & 1 & 1 & 0 & 0 \\
\hline Pythium de Baryanum. & 1 & 1 & 0 & 0 \\
\hline Pythium rostratum..... & 1 & 1 & 0 & 0 \\
\hline Pythium ultimum.... & 9 & $31 \dagger$ & 3 & 7 \\
\hline Pythium vexans... & 2 & 3 & 1 & 2 \\
\hline
\end{tabular}

* Root samples were from citrus trees in 22 different localities.

$\dagger$ Of these roots, 20 (of 24 tested) were from 1 locality.

Pythium ultimum Trow was the fungus most frequently found in these root samples, occurring on 38 out of 472 roots from 12 out of 22 localities. Phytophthora citrophthora was next, occurring on 9 roots from 5 localities. Pythium vexans de Bary was found on only 5 roots from 3 localities; and the other fungi (table 1) came from only 1 locality each. The absence of a given fungus from a few samples of roots from a

\footnotetext{
${ }^{5}$ Identified by W. C. Snyder, Assistant Professor of Plant Pathology and Assistant Plant Pathologist in the Experiment Station.

${ }^{6}$ Culture tests made from roots of citrus trees affected with a condition known as "dry root rot" have generally yielded Fusarium Solani. Attempts by various workers (3), however, to reproduce the disease by inoculation, with this fungus, of trees growing under healthy conditions, have yielded negative results.

To test the possible effect of Fusarium further, large numbers of young citrus trees, including some three-year-old trees growing in 5-gallon cans, were inoculated with the Fusarium Solani common in the more recent isolation tests by introducing the fungus, growing on sterilized wheat kernels, into the top layers of the soil without disturbing the roots. A month later, a number of these plants were submerged - in larger containers of water for periods varying from 3 days to 3 weeks. They were then drained rapidly and were watered thereafter whenever necessary. During the following 6 months, none of these plants showed any ill effects from the presence of the fungus or from the period of submersion.
} 
given tree is not much of an indication, however, that it was not to be found on that tree. In a study of fungi on avocado roots (10), Pythium ultimum was found on 1 root and Pythium vexans on 20.

\section{INOCULATION OF CITRUS FRUIT WITH PYTHIACEOUS FUNGI}

Inoculations were made on orange and lemon fruits with all the pythiaceous fungi recorded by Fawcett (3) and by Fawcett and Bitancourt (4), namely, Phytophthora citrophthora (Sm. and Sm.), Phytophthora parasitica Dastur, Phytophthora palmivora Butler, Phytophthora Syringae Kleb. (=P. hibernalis Carne), Phytophthora cactorum (L. and C.) Schroet. ( $=P$. citricola Saw.), Phytophthora megasperma, and Phytophthora Cinnamomi Rands; and by Wager $(8,9)$, namely, $P y$ thium irregulare Buis. from a rotting orange and Pythium ultimum Trow from the navel end of a young orange. These fungi included all the Pythiaceae previously obtained from citrus, with the exception of Pythium megalacanthum de Bary.

The relative importance of deep and shallow wounds (that is, those which penetrate the juice sacs and those which do not) in the production of rots caused by Alternaria Citri Ellis and Pierce and Fusarium lateritium Nees has been demonstrated (9). Accordingly, in these tests, inoculum (fungus growing on agar) was placed on the surface of the fruit and in shallow wounds, being covered in both cases with damp absorbent cotton; or it was placed in deep wounds made with a cork borer and sealed with vaseline. The results are presented in table 2 .

Phytophthora citrophthora, P. parasitica, P. palmivora, and P. cactorum produced a brown rot of fruits, whether the inoculum was placed on the surface of the uninjured fruit or in shallow or deep wounds. The fruits inoculated with $P$. Syringae were kept at $18^{\circ} \mathrm{C}$; there was no infection through uninjured epidermis, and the rot developed very slowly both in shallow and in deep wounds.

Phytophthora megasperma did not produce infection through uninjured epidermis, but did induce a slow, brown, leathery rot through shallow or deep wounds. P. Cinnamomi was also unable to pierce uninjured epidermis ; through wounds, it produced a firm, brown, leathery rot, which was inclined to be of a drier type inside than that produced by the other species.

Pythium ultimum and Pythium de Baryanum were able, in a few cases, to infect through uninjured skin. Both of these fungi, through shallow or deep wounds, produced a brown rot and wrinkling of the skin, grew rapidly to the core, and traveled to both ends of the fruit, 
TABLE 2

Infection of Citrus Fruits by Inoculation with Pythiaceous Fungi

\begin{tabular}{|c|c|c|c|c|c|}
\hline \multirow{3}{*}{$\begin{array}{l}\text { Fungus, culture no., and } \\
\text { source of culture }\end{array}$} & \multicolumn{5}{|c|}{$\begin{array}{l}\text { Number of fruits infected (of } 3 \text { inoculated) and rate of infection } \\
\text { (R, rapid; S, slow) }\end{array}$} \\
\hline & \multicolumn{2}{|c|}{ Oranges } & \multicolumn{3}{|c|}{ Lemons } \\
\hline & \begin{tabular}{|c|} 
Surface \\
inoculation
\end{tabular} & $\begin{array}{c}\text { Deep } \\
\text { wound }\end{array}$ & $\begin{array}{c}\text { Surface } \\
\text { inoculation }\end{array}$ & $\begin{array}{l}\text { Shallow } \\
\text { wound }\end{array}$ & $\begin{array}{c}\text { Deep } \\
\text { wound }\end{array}$ \\
\hline \multicolumn{6}{|l|}{ Phytophthora cactorum: } \\
\hline $2016,{ }^{*}$ from lemon fruit, Brazil. & $3 \mathrm{R}$ & $3 \mathrm{R}$ & $3 \mathrm{R}$ & $3 \mathrm{R}$ & $3 \mathrm{R}$ \\
\hline $292, \dagger$ from grapefruit, South Africa... & $3 \mathrm{~S}$ & $3 \mathrm{~s}$ & $2 \mathrm{~S}$ & $3 \mathrm{~S}$ & $2 \mathrm{~S}$ \\
\hline \multicolumn{6}{|l|}{ Phytophthora Cinnamomi: } \\
\hline $2009,{ }^{*}$ from orange bark, Brazil...... & 0 & $3 \mathrm{R}$ & 0 & $3 \mathrm{R}$ & $3 \mathrm{R}$ \\
\hline $385, \ddagger$ from avocado root, South Africa. & 0 & $3 \mathrm{~S}$ & 0 & $3 \mathrm{~S}$ & $3 \mathrm{~S}$ \\
\hline 6, from avocado root, California..... & 0 & $3 \mathrm{~S}$ & 0 & $3 \mathrm{~S}$ & $3 \mathrm{R}$ \\
\hline 15 , from avocado root, California..... & 0 & $3 \mathrm{~S}$ & $\ldots$ & $\ldots$ & $\ldots$ \\
\hline \multicolumn{6}{|l|}{ Phytophthora citrophthora: } \\
\hline $1309,{ }^{*}$ from lemon bark, California.... & $3 \mathrm{R}$ & $3 \mathrm{R}$ & $3 \mathrm{R}$ & $3 \mathrm{R}$ & $3 \mathrm{R}$ \\
\hline $3222, \ddagger$ from orange fruit, South Africa. & $3 \mathrm{R}$. & $3 \mathrm{R}$ & $3 \mathrm{R}$ & $3 \mathrm{R}$ & $3 \mathrm{R}$ \\
\hline 29 , from orange root, California....... & $2 \mathrm{~S}$ & $3 \mathrm{R}$ & $3 \mathrm{R}$ & $3 \mathrm{R}$ & $3 \mathrm{R}$ \\
\hline 52, from lemon root, California.. & $2 \mathrm{R}$ & $3 \mathrm{R}$ & $\ldots$ & $\ldots$ & $\ldots$ \\
\hline \multicolumn{6}{|l|}{ Phytophthora megasperma: } \\
\hline $1851, *$ from orange root, California. & 0 & $3 \mathrm{~s}$ & 0 & $3 \mathrm{~S}$ & $2 . \mathrm{S}$ \\
\hline \multicolumn{6}{|l|}{ Phytophthora palmivora: } \\
\hline $2003,{ }^{*}$ from orange bark, Argentina.. & $2 \mathrm{~S}$ & $3 \mathrm{~s}$ & $2 \mathrm{~S}$ & $3 \mathrm{R}$ & $3 \mathrm{R}$ \\
\hline \multicolumn{6}{|l|}{ Phytophthora parasitica: } \\
\hline $2011,{ }^{*}$ from orange bark, Brazil....... & $3 \mathrm{~S}$ & $3 \mathrm{R}$ & $3 \mathrm{R}$ & $3 \mathrm{R}$ & $3 \mathrm{R}$ \\
\hline $32, \ddagger$ from orange root, California....... & $3 \mathrm{R}$ & $3 \mathrm{R}$ & $3 \mathrm{R}$ & $3 \mathrm{R}$ & $3 \mathbf{R}$ \\
\hline \multicolumn{6}{|l|}{ Phytophthora Syringae: } \\
\hline $1894,{ }^{*}$ from orange fruit, California.... & 0 & $3 \mathrm{~S}$ & 0 & $3 \mathrm{~S}$ & $3 \mathrm{~S}$ \\
\hline $1839,{ }^{*}$ from orange fruit, California.... & 0 & $3 \mathrm{~S}$ & 0 & $3 \mathrm{~S}$ & $3 \mathrm{~S}$ \\
\hline \multicolumn{6}{|l|}{ Pythium de Baryanum: } \\
\hline 13 , from orange root, California. & $\mathbf{0}$ & $3 \mathrm{R}$ & $1 \mathrm{R}$ & $3 \mathrm{R}$ & $3 \mathrm{R}$ \\
\hline \multicolumn{6}{|l|}{ Pythium irregulare: } \\
\hline 90 , from orange fruit, South Africa. & 0 & $1 \mathrm{~S}$ & 0 & $2 \mathrm{~S}$ & $1 \dot{\mathrm{S}}$ \\
\hline \multicolumn{6}{|l|}{ Pythium rostratum: } \\
\hline 37 , from orange root, California. . & 0 & 0 & 0 & 0 & 0 \\
\hline \multicolumn{6}{|l|}{ Pythium ultimum: } \\
\hline 1, from orange root, California........ & $1 \mathrm{R}$ & $3 \mathrm{R}$ & 0 & $3 \mathbf{R}$ & $3 \mathrm{R}$ \\
\hline 42, from lemon root, California.......... & $1 \mathrm{R}$ & $3 \mathrm{R}$ & $1 \mathrm{~S}$ & $3 \mathrm{R}$ & $3 \mathrm{R}$ \\
\hline \multicolumn{6}{|l|}{ Pythium vexans: } \\
\hline 30, from orange root, California....... & 0 & $3 \mathrm{~s}$ & 0 & $3 \mathrm{~S}$ & $3 \mathrm{~S}$ \\
\hline 38 , from orange root, California...... & 0 & $3 \mathrm{~s}$ & 0 & $3 \mathrm{~S}$ & $3 \mathbf{S}$ \\
\hline
\end{tabular}

* Isolated by Fawcett.

t Isolated by Doidge.

† Isolated by Wager.

which then also showed infection. The decay was a much softer and slushier type than that produced by the Phytophthora species. Pythium irregulare behaved similarly, but was much less virulent and rotted only a few of the inoculated fruits. Pythium vexans produced a distinctive rot both in shallow and in deep wounds; it progressed slowly, developed a sunken, brown, slushy area with a water-soaked zone surrounding it, 


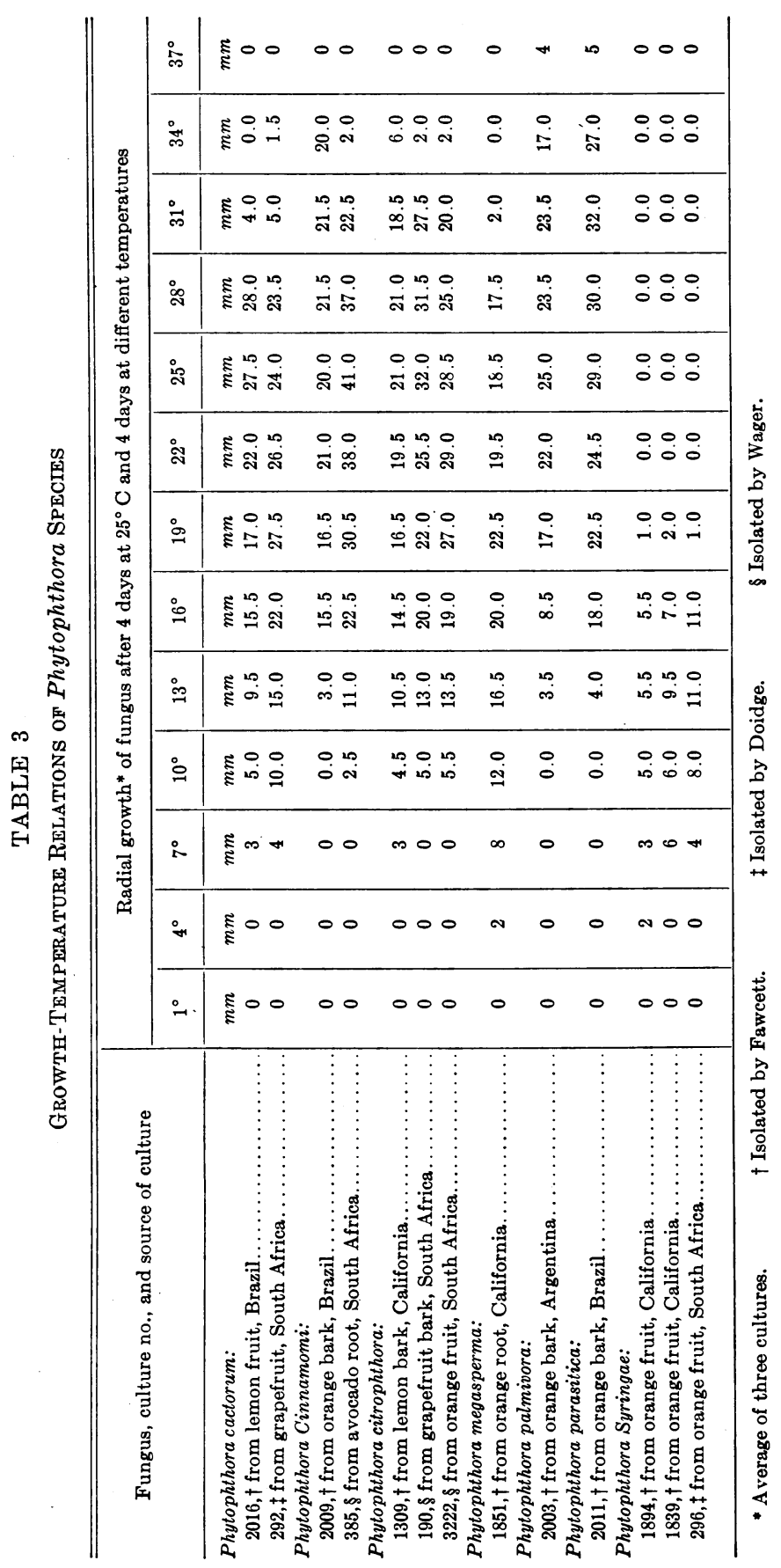


and was soft and slushy inside. Pythium rostratum Butler and one strain of Pythium vexans (with coiled antheridial branch) did not produce any infection at all.

\section{GROWTH-TEMPERATURE RELATIONS OF PHYTOPHTHORA SPECIES}

The growth-temperature relations of Phytophthora species, based on radial growth of the mycelium in culture, are shown in table 3 . The results agree with those of Fawcett and Bitancourt (4).P. parasitica has a slightly higher maximum than $P$. citrophthora; and $P$. parasitica, $P$. palmivora, and P. Cinnamomi from citrus in Brazil grew well at $34^{\circ}$ C. $P$. Syringae is a low-temperature fungus, not growing at $22^{\circ}$ or above and showing maximum growth between $13^{\circ}$ and $16^{\circ}$. P. megasperma also has a low maximum, $19^{\circ}$.

\section{DISTRIBUTION OF PHYTOPHTHORA SPECIES ON CITRUS}

The world distribution of the Phytophthora species on citrus, as compiled from Fawcett's (3) records and from a survey of phytopathological literature up to 1940 , is as follows:

Phytophthora cactorum:
Argentina
Brazil
Japan
South Africa
Phytophthora Cinnamomi:
Brazil
United States-California
Phytophthora citrophthora:
Argentina
Australia-New South Wales, Queens-
$\quad$ land, South Australia, Victoria, and
$\quad$ West Australia
Azores
Belgian Congo
Brazil
Cyprus
Egypt
India
Italy
Japan
Mexico
Mozambique
New Zealand
Palestine

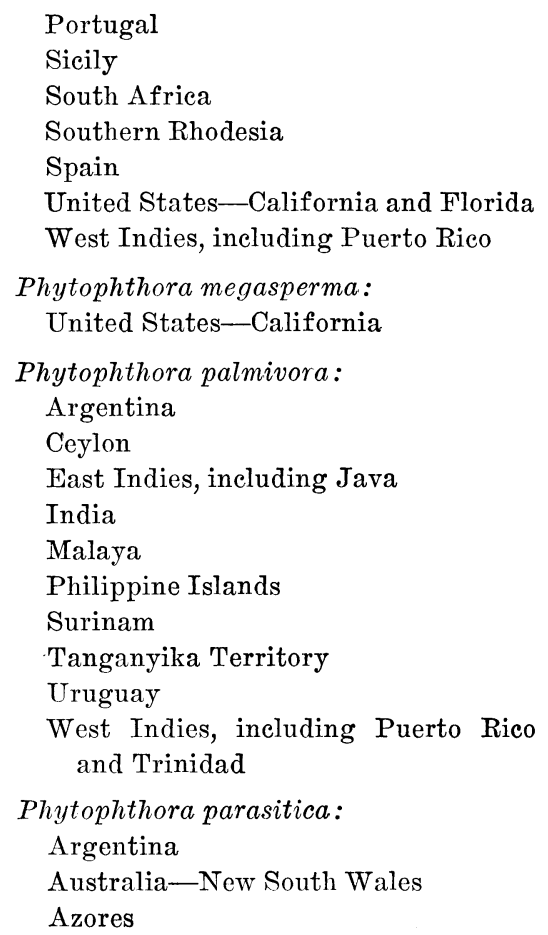




\section{IDENTIFICATION OF PYTHIACEOUS FUNGI ON CITRUS}

For convenience in identifying Pythiaceae found on citrus, the characteristics of Phytophthora species are given in table 4 (see also fig. 1), and those of Pythium species in table 5 (see also fig. 2). All cultures described in these tables were examined by the writer except Pythium megalacanthum.

According to Tucker ( 7 ), the names Phytophthora hibernalis and $P$. citricola should be discarded in favor of $P$. Syringae and P. cactorum, respectively. Fawcett's cultures $1894 P$. Syringae and $1839 P$. hibernalis were found very similar in their cultural and morphological characters and in their reactions when inoculated into citrus fruits and are herein considered to be $P$. Syringae. 


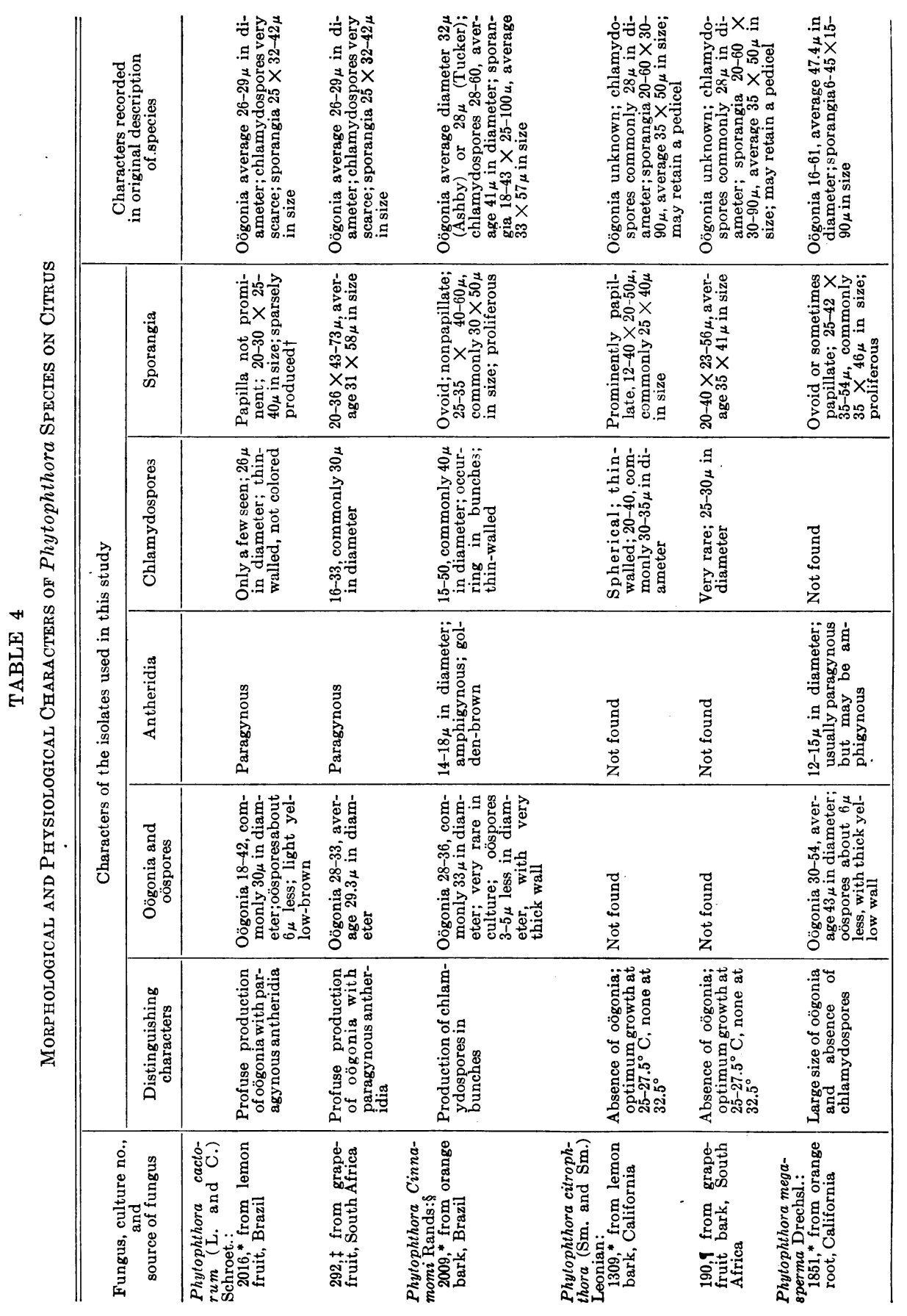




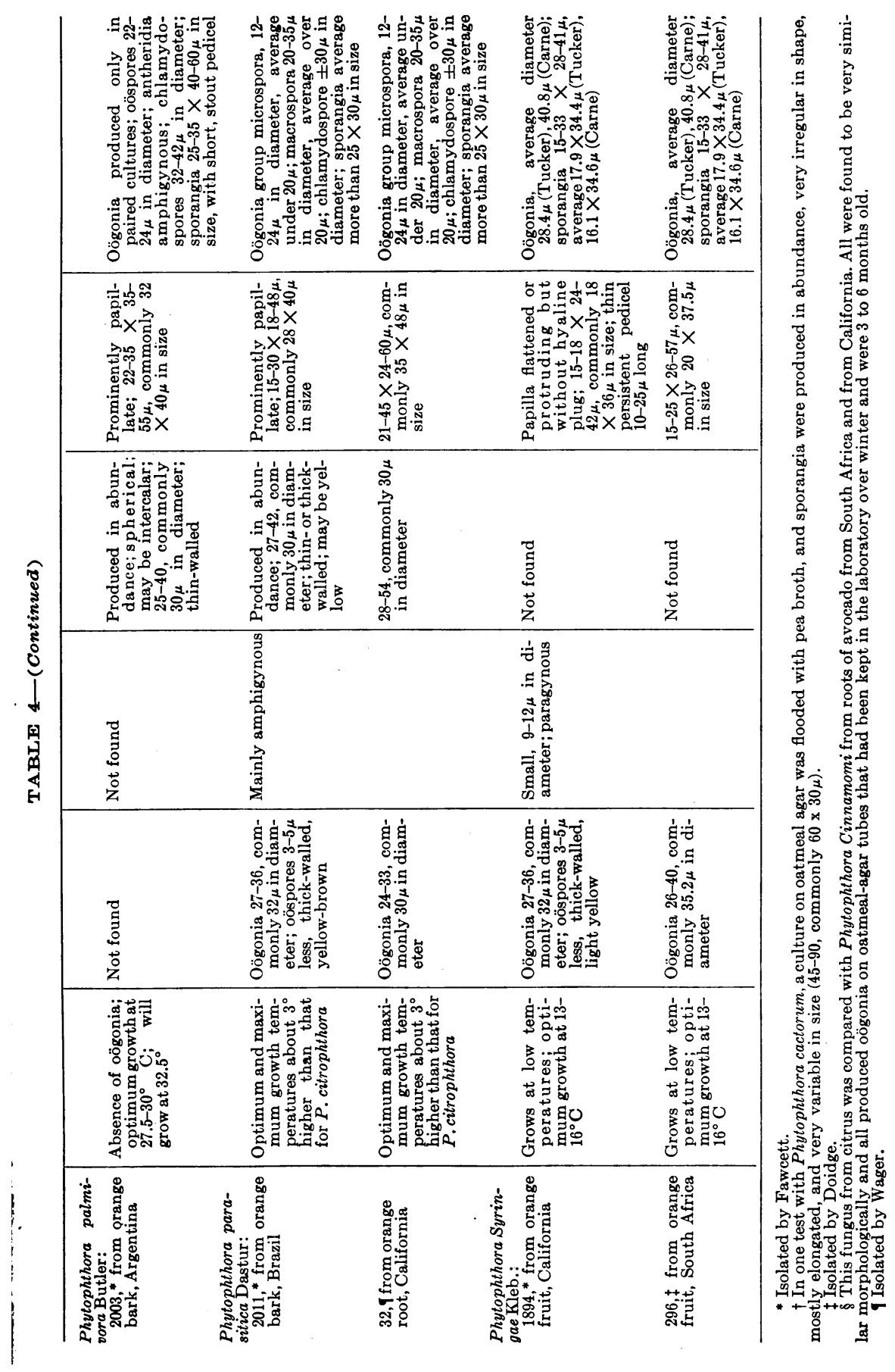




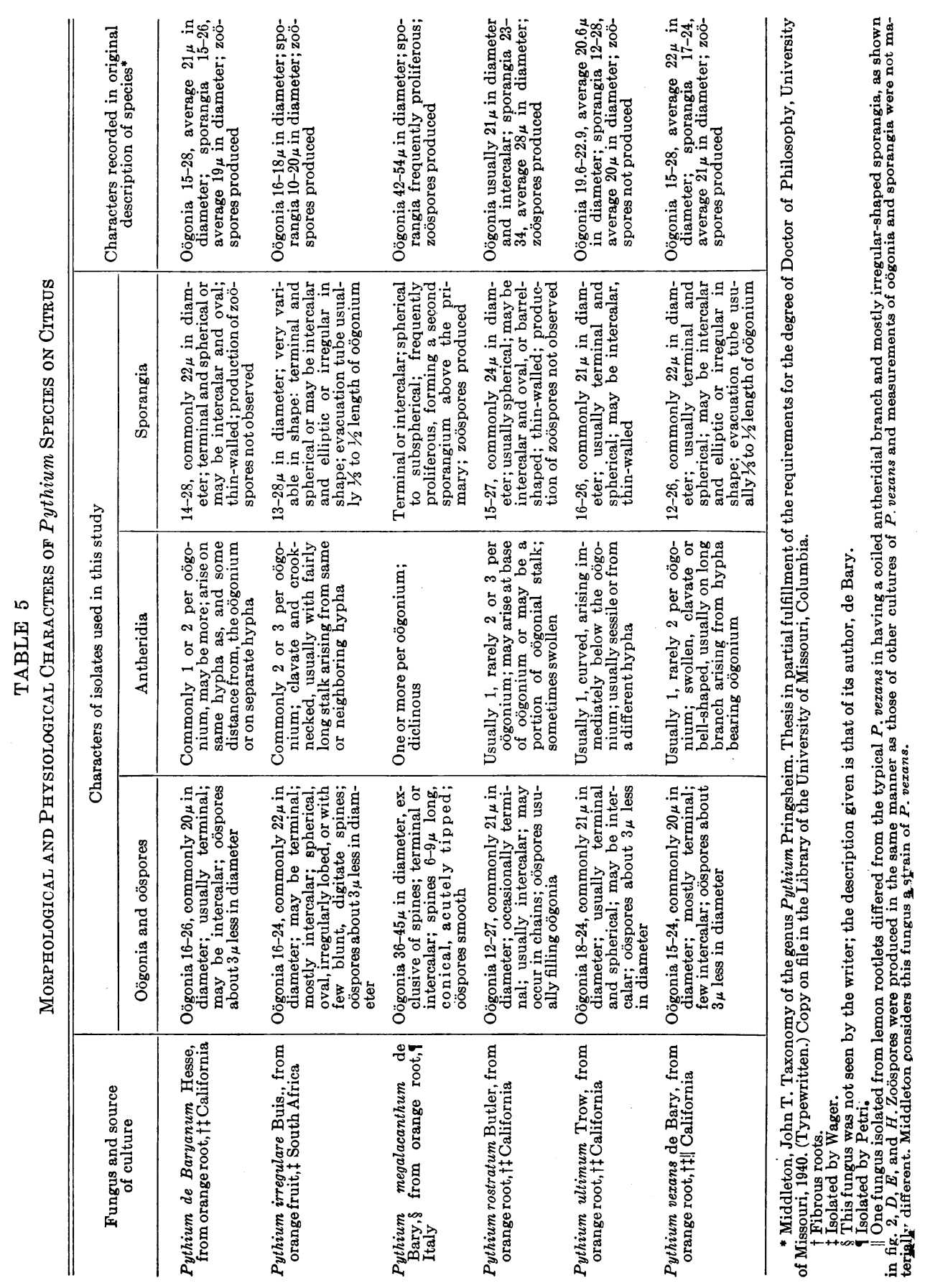




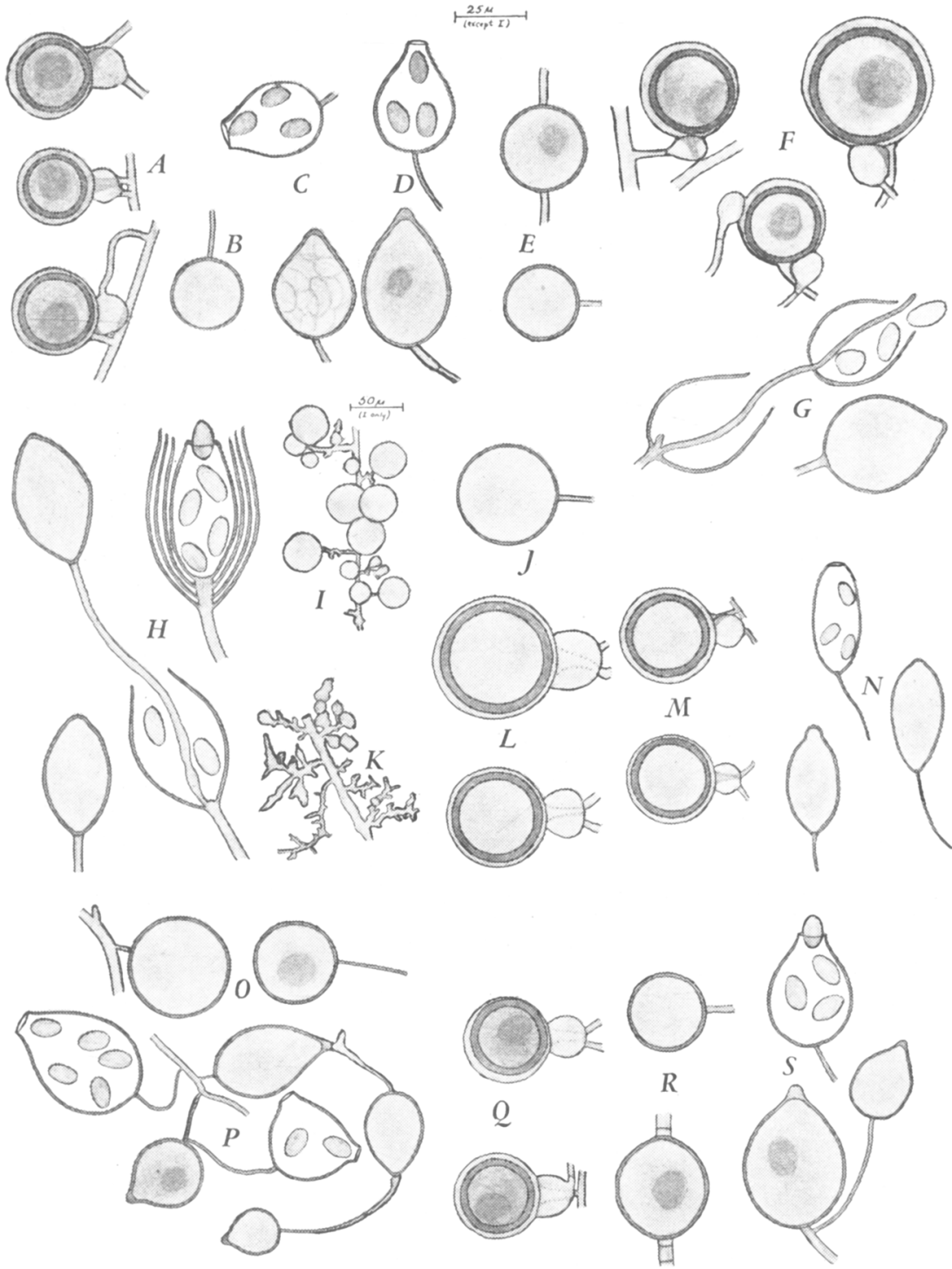

Fig. 1.-Phytophthora species. A-C, Phytophthora cactorum (L. and C.) Schroet.: $A$, oögonia and paragynous antheridia; $B$, chlamydospore; $C$, sporangia. $D-E, P h y$ tophthora palmivora Butler: D, sporangia; $E$, chlamydospores. $F-G$, Phytopthora megasperma Drechsl.: $F$, oögonia and paragynous antheridia; $G$, sporangia. $H-L$, Phytophthora Cinnamomi Rands: $H$, sporangia; $I, J$, chlamydospores; $K$, mycelium; $L$, oögonia and amphigynous antheridia. $M-N$, Phytophthora Syringae Kleb.: $M$, oögonia and paragynous antheridia; $N$, sporangia with persistent pedicels. $O-P$, Phytophthora citrophthora (Sm. and Sm.) Leonian: $O$, chlamydospores; $P$, sporangia. $Q-S$, Phytophthora parasitica Dastur: $Q$, oögonia and amphigynous antheridia; $R$, chlamydospores; $S$, sporangia. 

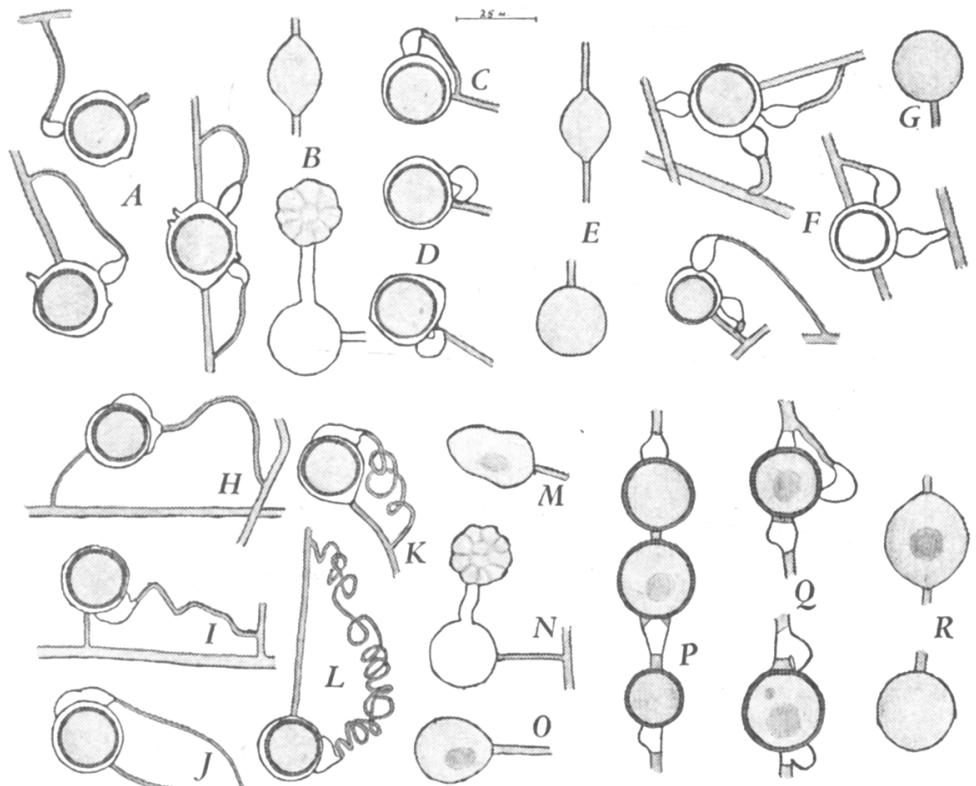

Fig. 2-Pythium species. $A-B$, Pythium irregulare Buis.: $A$, antheridia and oögonia; $B$, sporangia. $C-E$, Pythium ultimum Trow: $C$, stalked antheridium that occurs rarely; $D$, common type of antheridium and oögonium; $E$, sporangia. $F-G$, Pythium de Baryanum Hesse: $F$, antheridia and oögonia; $G$, sporangium. $H-O$, Pythium vexans de Bary: $H, I, J, K, L$, oögonia and antheridia; $M, N$, and $O$, sporangia; $K, L$, and $M$ are of a strain of the fungus from lemon rootlets and differ somewhat from other forms in having a coiled antheridial branch and irregular-shaped sporangia. $P-R$, Pythium rostratum Butler: $P$ and $Q$, antheridia and oögonia; $R$, sporangia. 


\section{SUMMARY}

Cultures were made from fibrous dead roots of orange and lemon trees growing in various localities in southern California and showing a dying-back, or decline.

Pythium ultimum, Pythium de Baryanum, Pythium vexans, Pythium rostratum, Phytophthora citrophthora, and Phytophthora parasitica were found on some of these roots, Pythium ultimum being the most frequent. The occurrence of the last-named fungus was very infrequent, however, in comparison with that of the nonpythiaceous fungus Fusarium Solani, which was found on almost every root.

The results of inoculation tests on orange and lemon fruits with the aforementioned Pythium species, with Pythium irregulare, and with all the Phytophthora species that have been isolated from citrus, namely, Phytophthora citrophthora, Phytophthora parasitica, Phytophthora palmivora, Phytophthora Syringae, Phytophthora cactorum, Phytophthora Cinnamomi, and Phytophthora megasperma are reported in this paper.

The distribution of the Phytophthora species and descriptions of the morphological characters of the Phytophthora and Pythium species which have been recorded on citrus are given.

\section{ACKNOWLEDGMENT}

The writer wishes to thank Dr. H. S. Fawcett for his suggestions and for the interest which he took in this work during the year that the writer spent at the University of California Citrus Experiment Station. 


\section{LITERATURE CITED}

1. FAWCETT, HoWARD S.

1923. Gummosis of Citrus. Jour. Agr. Res. 24:191-236.

2. FAWCETT, HoWARD S.

1933. New locations for Phytophthora citrophthora and P. hibernalis on Citrus. Phytopathology $23: 667-69$.

3. FAWCETT, HOWARD S.

1936. Citrus diseases and their control. 656 p. $2 \mathrm{~d}$ ed. McGraw-Hill Book Company, Inc., New York, N. Y.

4. FAwCETT; H. S., and A. A. Bitancourt.

1940. Occurrence, pathogenicity, and temperature relations of Phytophthora species on citrus in Brazil and other South American countries. Inst. Biol. Arch. 11:107-18.

\section{Perlberger, J.}

1936. Phytophthora stem and tip blight of Citrus seedlings. Hadar 9(6-7): 145-50.

6. PETRI, L.

1935. Pythium megalacanthum Rassegna dei casa fitopatologici osservati nel 1934. [Roma] R. Staz. di Patol. Veg. Bol. 15:1-95.

7. TUCKER, C. M.

1931. Taxonomy of the genus Phytophthora de Bary. Missouri Agr. Exp. Sta. Res. Bul. 153:1-208.

8. WAGER, VINCENT A.

1931. Diseases of plants in South Africa due to members of the Pythiaceae. Union So. Africa Dept. Agr. [Sci.] Bul. 105:1-43.

9. WAGER, VINCENT A.

1939. The navel-end-rot, splitting, and large-navel-end problems of Washington Navel oranges in the Kat River Valley. Union So. Africa Dept. Agr. Sci. Bul. 192:1-20.

10. WAGER, VINCENT A.

1942. Phytophthora Cinnamomi and wet soil in relation to the dying-back of avocado trees. Hilgardia 14(9) :517-32.

11. Weinding, R.

1932. Trichoderma lignorum as a parasite of other soil fungi. Phytopathology $22: 837-45$. 